\title{
The Core Elements of Representative Democracy within Inter-American Law
}

\author{
Los elementos centrales de la democracia \\ representativa en el derecho interamericano
}

Les éléments fondamentaux de la démocratie représentative dans le droit interaméricain

\author{
Elizabeth Jiménez Mora*
}

Summary: I. Introduction. II. The Core of the Concept of Democracy. III. The Genesis of the Relationship between Representative Democracy and Human Rights in the American States. IV. The Elements of Representative Democracy. V. Conclusion. VI. Acknowledgements. VII. Bibliography.

* Centre for Civil and Political Rights, Switzerland; ORCID ID: https: / / orcid.org/0000-00 02-1828-7885,elizabethjm8@hotmail.com. 
RESUMEN: A partir de los instrumentos y acuerdos interamericanos es posible identificar la relevancia de la democracia para los Estados americanos. Sin embargo, la democracia no es un concepto claro, por lo que este artículo presenta los derechos mínimos que deben ser protegidos para considerar un régimen como democrático. Estableciendo la conexión entre la teoría de la democracia y el derecho, se concluye que una democracia representativa requiere que los Estados americanos garanticen algunos estándares mínimos para proteger y garantizar: 1) la igualdad; 2) la libertad de reunión; 3) la libertad de expresión; 4) los derechos políticos, y 5) la independencia judicial. Los cinco elementos mencionados constituyen el núcleo mínimo de la democracia representativa, mas no son los únicos derechos importantes para un régimen democrático.

Palabras clave: democracia, igualdad, libertad de reunión, libertad de expresión, derechos políticos, independencia judicial.

ABSTRACT: From the Inter-American instruments and agreements it is possible to identify the relevance of democracy for the States of the Americas. However, this is not a clear concept, consequently this paper presents the minimum rights that have to be protected in order to consider a regime as democratic. The present paper builds the connection between the theory of democracy and the law, concluding that a representative democracy requires American States to guarantee some minimum standards to protect and guarantee: 1) equality; 2) freedom of assembly; 3) freedom of expression; 4) political rights, and 5) judicial independence. The five elements mentioned constituted the minimum core of representative democracy, but they are not the only rights important for a democratic regime.

Key words: democracy, equality, freedom of assembly, freedom of expression, political rights, judicial independence.

RÉSUMÉ: À partir des instruments et accords interaméricains, il est possible d'identifier la pertinence de la démocratie pour les États des Amériques. Cependant, ce concept n'est pas clair, par conséquent ce document présente les droits minimums qui doivent être protégés afin de considérer un régime comme démocratique. Le présent document établit le lien entre la théorie de la démocratie et le droit, en concluant qu'une démocratie représentative exige des États américains qu'ils garantissent certaines normes minimales pour protéger et garantir: 1) l'égalité; 2) la liberté de réunion; 3) la liberté d'expression; 4) les droits politiques, et 5) l'indépendance judiciaire. Les cinq éléments mentionnés constituaient le noyau minimum de la démocratie représentative, mais ce ne sont pas les seuls droits importants pour un régime démocratique.

Mots-clés: démocratie, égalité, liberté de réunion, liberté d'expression, droits politiques, indépendance judiciaire. 


\section{INTRODUCTION}

Every individual should say the phrase of Louis XIV: "I am the state".

Rudolf von IHERING

For the States of the Americas, democracy has been a huge concern. However, there is no clear definition and understanding of what democracy is, and as a consequence democracy has become a tool of propaganda. As George Orwell said,

...[i]n the case of a word like democracy, not only is there no agreed definition, but the attempt to make one is resisted from all sides. It is almost universally felt that when we call a country democratic, we are praising it: consequently, the defenders of every kind of régime claim that it is a democracy, and fear that they might have to stop using the word if it were tied down to any one meaning. Words of this kind are often used in a consciously dishonest way. ${ }^{1}$

Precisely because of the accuracy of the affirmation made by George Orwell, the present work will identify and develop the necessary elements that constitute a representative democracy in the American countries, under international law.

Democracy could be argued as a universal concept, right or form of government, depending on the view from which it is studied. Example of this is the shy implied mention of it in the Universal Declaration on Human Rights in its article $21 .^{2}$ In recent years experts have made reference to seve-

1 Orwell, George, "Politics and the English Language", A Collection of Essays, United States of America, Harcourt Brace Jovanovich, 1946, p. 162.

2 Article 21 of the Universal Declaration establishes that: (1) Everyone has the right to take part in the government of his country, directly or through freely chosen representatives. (2) Everyone has the right of equal access to public service in his country. (3) The will of the people shall be the basis of the authority of government; this will shall be expressed in periodic and genuine elections which shall be by universal and equal suffrage and shall be held by secret vote or by equivalent free voting procedures. 
ral types of democracy. This can actually be seen in the systems that measure levels of democracy of States around the world, such as Varieties of Democracy (hereinafter V-Dem), which measures liberal democracy, electoral democracy, egalitarian democracy, deliberative democracy and participatory democracy. ${ }^{3}$

These multiple meanings can lead to the use of the word in a dishonest way by governments, presidents and candidates, as was explained by Orwell. However, the problem is not the number of definitions, because actually this responds to the fact that society evolved, and elements are continuously added to the definition in order to give answer to the new realities. The problem is that the core and basic requirements of a democracy are not necessarily clear, so it is easy to use an emblematic word such as democracy in a speech and play with the factors or elements that fit the ideas of the person that used it, even if this ideas violates the basic elements that constituted a democracy.

The American States, given their particular interest in the topic, have made many international efforts towards the protection and promotion of democracy within the continent. For this reason, it is essential to understand what are the basic elements that constitute a representative democracy in the Americas through an analysis of the concept since its beginnings until now. The present paper will build the connection between the theory of democracy and the law, studying the approximation that Regional Systems have given to these main components. These do not have to be understood such as that democracy have only the elements that are going to be analyze in the paper, the aim of it is to present the core elements of democracy and its development in the Americas perspective.

To make this analysis, the present paper will present first the core elements of the concept of democracy through an analysis of its origins and its philosophical development. Second, it is going to analyze the genesis of the relationship between representative democracy and human rights in the American States, given that representative democracy is within the wording of the Inter-American instruments. Third, reference will be made to the elements of representative democracy for the American States. These will lead to conclude that the core of representative democracy, under the InterAmerican System and the international obligations of the American States, is constituted by 1) equality, 2) freedom of assembly, 3) freedom of expres-

3 Official Website of Varieties of Democracy, available at: https: / /www.v-dem.net/es/. 
sion, 4) political rights and 5) judicial independence American States. States have to protect at least these rights to be consider a democracy, which by any means can be interpreted as the only rights important for a democratic regime or as an excuse to violate other human rights necessary for a healthy democracy.

\section{THE CORE OF THE CONCEPT OF DEMOCRACY}

Democracy is one of the best examples of an "essentially contested" concept because its meaning is object of endless dispute. ${ }^{4}$ Several definitions have been written around this concept. Going back to the core of the meaning, democracy is a Greek word that means "ruled by the people". The Greeks invented the idea, the word, and its practice. ${ }^{5}$ Athens practiced direct democracy, meaning that their citizens, which at that moment were just some men, where directly involved in the ruling of the State, instead of being represented by others. ${ }^{6}$ However, as Harrison pointed out, Greek citizens had time to discuss, and participated in their society through direct democracy because they had slaves. ${ }^{7}$ They understood democracy as self-government or autonomy of the community (polis). ${ }^{8}$ Even when they didn't consider women and slaves as citizens, between whom they considered citizens, they were equal before the law. This was one most of the important values of their democracy. ${ }^{9}$

Aristotle placed the critique that in this model a "democracy serves the interest of the majority and not the people as a whole". ${ }^{10}$ For this reason, he explores the idea of "polity", ${ }^{11}$ that can be translated to constitutional

4 Coppedge, Michael, Democratization and Research Methods, New York, Cambridge University Press, 2013, p. 11.

5 Harrison, Ross, Democracy, London-New York, Routledge, 1993, p. 2; Lakoff, Sanford, Democracy: History, Theory, Practice, New York, Westview Press, 1996, p. 37.

6 Ibidem, p. 16.

7 Idem.

8 Lakoff, Sanford, op. cit., p. 37.

9 Harrison, Ross, op. cit., p. 17.

10 Ibidem, p. 29.

11 Dahl, Robert, Democracy and its Critics, Yale University, 1989, pp. 14-18. 
government. This would be a democracy also ruled by the majority but favoring the common interest and their idea of what is just. In his understanding, justice is connected with equality, and this was one of the most important values of democracy. ${ }^{12}$

This understanding of democracy then changes with the Romans and the latter Republicanism. In Roman republicanism, "the public opinion had only a restricted role in which power was divided among different assemblies, with an aristocratic senate". ${ }^{13}$ For them the ultimate authority was in their citizens, that excluded women, but they divided legislative and elective authority and the popular assemblies voted by group rather than by individual suffrage. ${ }^{14}$ Through this means, Roman republicanism tried to find the balance between the sharing power among the major groups composing society and the respect of the social hierarchy. ${ }^{15}$ The ideology of the Roman republicanism was that Libertas or freedom "consist not in the power of do as one pleases but to live according to the law which applies equally to all, and the law is respected because it is understood to be extremely advantageous to all". ${ }^{16}$ Even with social hierarchy, the Christian teaching was present and its greatest implication for democracy was that "humanity was created in the image of God, all humans are of equal worth in the sight of God". ${ }^{17}$ The acceptance of equality was understood as a spiritual equality different from the earthly hierarchy, ${ }^{18}$ but still the sense of this latter principle was present at the time.

The next important step of democracy in history comes with Locke and Rousseau, who didn't necessarily make reference to the term democracy. However, their theories are applicable to the analysis of the concept because they share values with the initial concept of democracy. John Locke claimed that men are by nature free, equal and independent and that a State of liberty implies that people are free to act without government interference. ${ }^{19}$ However, for him, men seek "to preserve this original liberty and

12 Harrison, Ross, op. cit., p. 31.

13 Lakoff, Sanford, op. cit., p. 65.

14 Idem.

15 Idem.

16 Ibidem, p. 79.

17 Ibidem, p. 90.

18 Ibidem, p. 92.

19 Harrison, Ross, op. cit., p. 49. 
equality on entry into political society". ${ }^{20}$ For this reason, an adequate State must grant equal respect of such rights to all the. For this purpose, people have the right to rebellion or revolution against a government that does not preserve their rights. ${ }^{21}$ As Locke establishes: “... when any number of Men have, by the consent of every individual, made a Community, they have thereby made that Community one Body, with a Power to Acts as one Body, which is only by the will and determination of the majority". ${ }^{22}$

Rousseau was focused on liberty and equality as well. However, the concept of liberty between Locke and Rousseau is different, because for Locke, freedom is understood in a "negative" way. It is essentially being left alone. On the other hand, freedom according to Rousseau is "positive" in the sense that someone will be free only if she or he are capable to do certain things. ${ }^{23}$ According to Rousseau, each person puts his power under the supreme direction of the general will, making the difference between general will and the will of all. With this argument, Rousseau remarks that the general will considers the common interest and the will of all is just a sum of particular wills. ${ }^{24} \mathrm{He}$ establishes that:

...the social compact sets up among the citizens an equality of such kind, that they all bind themselves to observe the same conditions and should therefore all enjoy the same rights. Thus, from the very nature of the compact, every act of sovereignty, i.e. every authentic act of general will, binds or favours all the citizens equally. ${ }^{25}$

Tocqueville meanwhile talks about political passions. "In a large republic", he declared: "political passions become irresistible, not only because the object they pursue is immense, but more because millions of men feel them in the same way at the same moment" ${ }^{26}$ Drescher explains that for Tocqueville "consciously or unconsciously modern man was choosing between the patriotism of all and rule by the few, «for one cannot unite the force and the social activity rendered by the first with the guarantees of tranquility

20 Ibidem, p. 50.

21 Ibidem, p. 49.

22 Ibidem, p. 47.

23 Ibidem, p. 53.

24 Ibidem, pp. 54 and 55.

25 Ibidem, p. 56.

26 Drescher, Seymour, “Tocqueville's Two Democraties", Journal of the History of Ideas, vol. 25, no. 2, 1964, p. 203. 
sometimes provided by the second»". ${ }^{27}$ In 1835 , Tocqueville talked about the tyranny of the majority when it is excessive power of the people. In this sense, he concludes that the omnipotence of the majority stated "by the misuse of their power and not by impotence that democratic republics were exposed to destruction". ${ }^{28}$ He explains the "great triumph of America had been its ability to «confine within a narrow sphere the turbulent ambition of its citizens»" ${ }^{29}$ by "creating vigorous institutions of local government, by balancing political mobility against a fixed religious morality, and by fostering the habit of regulated public activity to control worse appetites and ambitions". ${ }^{30}$

In relation to this, it is important to mention what John Stuart Mill pointed out. Mill didn't agree with "Tocqueville's view that democracy must inevitably mean majority rule", ${ }^{31}$ because that will cause "class legislation". For that reason, he explained that suffrage is not enough to guarantee that people will govern themselves or that the legislator would promote their personal interests. ${ }^{32}$ He proposed proportional representation, to control the majority; "weighted voting, to allowed the educated greater influence"; and widespread participation in government, to ensure that everyone participated in self-governance. ${ }^{33}$ In consequence, "Mill's aim was to propose a system of representative government combining competence and participation". ${ }^{34}$

It is also important to make reference about Marx and Hegel and their positions towards democracy. Both authors contradict many of the affirmations made by the philosophers mentioned before, so it is important to analyze their alternative way of thinking about democracy. Marx had three basic points regarding democracy. First, he argues that "democracy represents more than a set of legal forms or procedures, realizing «the essence of every state» in such a way that other constitutional forms appear by contrast as merely juridical entities". ${ }^{35}$ Second, he states that democracy "does

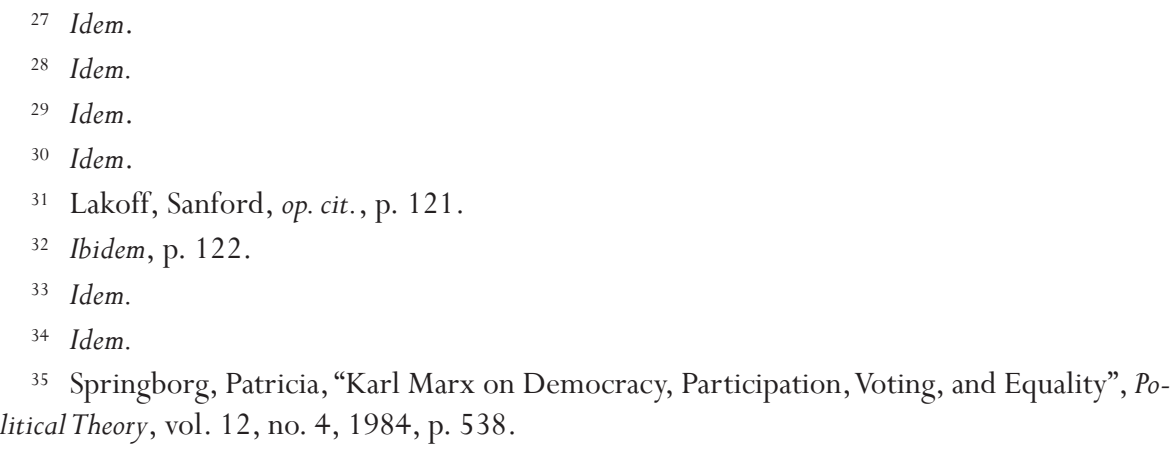


not require the participation of all members of society as individuals in the decision-making process and that, therefore, the debate over the relative merits of direct or representative democracy is misdirected" ${ }^{36}$ Finally, Marx argues that "political participation turns not on the function of deputies or representatives but rather on political suffrage". ${ }^{37}$

On the other hand, Hegel, as Montesquieu, argues that democracy is based on the principle of virtue and therefore it depends on the sense of duty, and this constitutes a weakness of democracy. ${ }^{38}$ For him "the sovereignty of the people is one of the confused notions based on the wild idea of the «people». Taken without its monarch and the articulation of the whole, which is the indispensable and direct concomitant of monarchy, the people is a formless mass and no longer a State". ${ }^{39}$

From the aforementioned ideologies, it is possible to identify common elements. Only Hegel presents a totally different approach which is difficult to reconcile with the essence of democracy since its origins, society "ruled by the people". Four common elements are present in the rest of the ideologies, equality, freedom, common will and self-government (according to the meaning of the word), understanding this through direct participation or representative participation.

The content of these common aspects may present some difficulty. First, differences existed in concepts such as freedom as was explained before between Rousseau and Locke. Second, equality may have different implications for the Greeks than now. For example, slavery is currently prohibited, and women are an essential part of society, so equality is broader than then. Third, common will may present difficulties in order to avoid understanding it as the will of the majorities affecting the rights of the minorities. Due to the differences mentioned, it is important to attempt to define democracy today. The aforementioned elements are going to be analyzed in detail later in the paper.

To understand how we define democracy now, it is useful to make reference to those systems created to measure democracy, given that they are created based on several definitions of democracy. Michael Coppedge is one

\footnotetext{
36 Idem.

37 Idem.

38 Ibidem, p. 540.

39 Idem.
} 
of the main investigators of Varieties of Democracy Project that was created for this purpose in 2011, and in his book Democratization and Research Methods he makes a great explanation of the difficulty to define democracy. ${ }^{40}$

Coppedge explains that even when it is possible to identify different types of definitions of democracy, all of them fit into "one of six overlapping models: socioeconomic, people's participatory, representative, liberal and deliberative democracy". ${ }^{41} \mathrm{He}$ explains that socioeconomic democracy "emphasizes the equalization of wealth, income, and status, both as a prerequisite for political equality and as an end in itself". ${ }^{42}$ Participatory democracies put main emphasis on the value of citizen involvement, further than just elections, because society and citizens will benefit from this participation. ${ }^{43} \mathrm{On}$ the other hand, deliberative democracy focuses on representation and participation, by promoting well-informed discussions of everything that could be of public interest. ${ }^{44}$

Representative democracy is present in all the democratic national states today in one way or another, because this type of democracy contains a "range running from popular sovereignty to liberal democracy". ${ }^{45}$ It considers the principle of popular sovereignty as a cornerstone, which holds that the majority rules, so whatever people want should become law. ${ }^{46}$ Finally, liberal democracy seeks to limit the power of the majority by guaranteeing some fundamental rights of individuals (and sometimes groups) and by creating constitutional checks on executive, legislative, and judicial powers. ${ }^{47}$

From the models mentioned by Coppedge, it is possible to identify the key components of democracy resulting from its origins, overlapping one another and leading towards a final definition of democracy. Equality derives from the socioeconomic definition. The common will from the liberal democracy worries about controlling the power of the majority. Participa-

40 Coppedge, Michael, op. cit.

41 Ibidem, p. 12.

42 Idem.

43 Idem; Pateman, Carole, Participation and Democratic Theory, Australia, Cambridge University Press, 1970.

44 Coppedge, Michael, op. cit., p. 12; Held, David, Models of Democracy, 3rd. ed., Great Britain, Stanford University Press, 2006.

45 Coppedge, Michael, op. cit., p. 12.

46 Idem.

47 Idem. 
tory democracies seek a benefit from the participation of the citizens for the society. Self-government can be identified in participative, deliberative, and representative democracies. Finally, the right to freedom can be derived from the liberal democracy that is concerned about fundamental rights of individuals.

In conclusion, four elements were and are present through all the definitions of democracy: 1) equality, 2) freedom, 3) common will, and 4) self-government through direct or representative participation. As was mentioned before, some challenges can appear trying to give a universal definition of each of these elements that reconcile all the particularities that were given by each philosopher in a specific moment in history.

To further address that difficulty, it is important to make reference to a regional approximation to democracy, to take a look of how the development of democracy in the American continent and its definition has been.

\section{The Genesis of the ReLationship BeTWEen RePRESENTATIVE DEMOCRACY AND Human RightS IN THE AMERICAN STATES}

Dating back to the firsts Inter-American conferences, the American States have had shown particular concern about democracy and its promotion in the region..$^{48}$ In the Charter of the Organization of American States (hereinafter also OAS Charter) in April of 1948 (amended in 1967, 1985, 1992 and 1993), the States of the Americas recognized the importance of democracy. In the preamble of the mentioned Charter the States established "that representative democracy is an indispensable condition for the stability, peace and development of the region". They acquired the obligation of the States to "promote and consolidate representative democracy" in article 2 of the Charter.

However, the definition of democracy doesn't appear in the Charter. The only approximation that the Charter has to give content to this obligation,

48 Arrighi, Jean Michel, "El sistema interamericano y la defensa de la democracia", Agenda Internacional, vol. 16, no. 27, 2009, pp. 69-94; Muñoz, Heraldo, "International Organizations and Democracy: The OAS and Democratic Governance”, Journal of Democracy, vol. 4, no. 3, 1993, pp. 29-38. 
comes from article 3 of the Charter of the OAS, which establishes the principle that required the States to fight against extreme poverty as part of its obligations of promotion and consolidation of democracy.

Nevertheless, at the gates of the Cold War, the Fifth Meeting of Consultation of Ministers of Foreign Affairs of the OAS was held in Santiago, Chile, in 1959. The Declaration that results from this meeting, defined some elements that could determine what constitutes a "representative democracy". The Declaration establishes that to be a representative democracy, the following components are required:

1. The principle of the rule of law must be ensured by the independence of the powers and the control of the legality of the acts of the government by State jurisdictional organs.

2. The governments of the American republics must arise from free elections.

3. The perpetuation of power, or the exercise of power without a fixed term and with a manifest purpose of perpetuation, are incompatible with the exercise of democracy.

4. The governments of the American States must maintain a regime of individual freedom and social justice based on respect for the fundamental rights of the human person.

5. Human rights embodied in the legislation of the American States must be protected by effective judicial means.

6 . The systematic use of political proscription is contrary to the American democratic order.

7. Freedom of the press, radio and television, and in general the freedom of information and expression are essential conditions for the existence of a democratic regime.

8. The American States, in order to strengthen democratic institutions, must cooperate with each other to the extent of their resources and within the terms of their laws to consolidate and develop their economic structure, and in order to achieve fair and humane living conditions for their people. ${ }^{49}$

This Declaration settled the first direct connections between established human rights and democracy. But it is not until the American Convention

49 Fifth Meeting of Consultation of Ministers of Foreign Affairs, Declaración de Santiago de Chile, Santiago (Chile), 1959, available at: https://www.oas.org/consejo/sp/RC/Actas/Ac ta\%205.pdf. 
Esta revista forma parte del acervo de la Biblioteca Jurídica Virtual del Instituto de Investigaciones Jurídicas de la UNAM

on Human Rights of December of 1969, that States settled in a binding document a clear relationship between some human rights, such as the rights of freedom of assembly and freedom of association, and a democratic society. $^{50}$

The relevance that democracy has for the States of the Americas is especially reflected in the Resolution 1080 of the General Assembly of the OAS in which States agree the possibility to impose sanctions among a State that don't respect democracy. This resolution state that the Secretary General has the possibility to ask the Permanent Council of the OAS to summon an immediate meeting to analyze and decide a situation in a country that generates an irregular interruption of a democratic government in one of the States of the OAS. ${ }^{51}$ From this meeting sanctions can be imposed to States as occurred already in Haiti in 1991, Perú in 1992 and Guatemala in 1993. ${ }^{52}$

In 2001 the member States of the OAS adopted in a special session of the General Assembly, the Inter-American Democratic Charter (hereinafter also Democratic Charter)..$^{53}$ The main purpose of this Inter-American instrument is being a tool to "update, interpret and apply the OAS Charter in topics of representative democracy". ${ }^{54}$ Article 1 of the Democratic Charter recognized expressly democracy as a right of the people of the Americas that

50 Article 15 of the American Convention establish: "The right of peaceful assembly, without arms, is recognized. No restrictions may be placed on the exercise of this right other than those imposed in conformity with the law and necessary in a democratic society in the interest of national security, public safety or public order, or to protect public health or morals or the rights or freedom of others".

Article 16(2) of the American Convention establish: "The exercise of this right shall be subject only to such restrictions established by law as may be necessary in a democratic society, in the interest of national security, public safety or public order, or to protect public health or morals or the rights and freedoms of others".

51 General Assembly of the OAS, "Representative Democracy", Resolution 1080 of June 5 of 1991, AG/RES. 1080 (XXI-O/91), operative paragraph 1, available at: https: / /www.oas. org/juridico/spanish/res-1080.htm.

52 To see the details of the cases, go to Arrighi, Jean Michel, op. cit.

53 OAS, "Tenth Anniversary of the Inter-American Democratic Charter was Commemorated in Chile with a Renewed Commitment of the Americas with Democracy", 2011, available at: https: / / www.oas.org/En/media_center/press_release.asp?sCodigo $=E-816 / 11$.

${ }^{54}$ Inter-American Juridical Committee, "Elementos esenciales y fundamentales de la democracia representativa y su vinculación con la acción colectiva en el marco de la Carta Democrática Interamericana”, Resolution CJI/RES (LXXXV-O/09), August 12, 2009, p. 604, available at: https: / / archivos.juridicas.unam. $m$ / $/ w w w / b j v / l i b r o s / 11 / 5130 / 30 . p d f$. 
had to be protected by governments. ${ }^{55}$ So, since 2001 it is possible to identify democracy not only in relation with human rights, but as a right itself.

However, the Democratic Charter doesn't define the scope of the right to democracy. Articles 3 and 7 of the Charter settle in a clear and direct way the relationship between human rights and democracy in different ways. Article 7 establishes that "[d]emocracy is indispensable for the effective exercise of fundamental freedoms and human rights in their universality, indivisibility and interdependence, embodied in the respective constitutions of states and in Inter-American and international human rights instruments". From this article it seems that democracy is a means for the compliance of human rights.

Nevertheless, article 3 of the Democratic Charter lists elements of representative democracy, leaving open the question if this means that the right to democracy is composed by others human rights. Article 3 establishes that the essential elements of representative democracy include: 1) respect for human rights and fundamental freedoms; 2) access to and the exercise of power in accordance with the rule of law; 3) the holding of periodic, free, and fair elections based on secret balloting and universal suffrage; 4) the pluralistic system of political parties and organizations, and 5) the separation of powers and independence of the branches of government. ${ }^{56}$ However, the Inter-American Court of Human Rights (hereinafter also IACoHR or Inter-American Court) interpreted article 3 of the Democratic Charter as the establishment of "the relationship between human rights, representative democracy and political rights", ${ }^{57}$ and not considering democracy as a right necessarily. In this sense, the Inter-American Court had established that "«[r]epresentative democracy is a determinant factor of the entire system of

55 The article 1 of the Inter-American Democratic Charter establish: "The peoples of the Americas have a right to democracy and their governments have an obligation to promote and defend it. Democracy is essential for the social, political, and economic development of the peoples of the Americas".

56 The article 3 of the Inter-American Democratic Charter establish: "Essential elements of representative democracy include, inter alia, respect for human rights and fundamental freedoms, access to and the exercise of power in accordance with the rule of law, the holding of periodic, free, and fair elections based on secret balloting and universal suffrage as an expression of the sovereignty of the people, the pluralistic system of political parties and organizations, and the separation of powers and independence of the branches of government".

57 I/ A Court H.R., Case of Castañeda Gutman v. Mexico. Preliminary Objections, Merits, Reparations, and Costs, Judgment of August 6, 2008, Series C No. 184, para. 142. 
which the Convention forms part», and constitutes «a 'principle' reaffirmed by the American States in the OAS Charter, a basic instrument of the InterAmerican system»" ${ }^{58}$

In conclusion, after identifying the relevant Inter-American instruments, it is still not clear if democracy is a right or a means to make human rights effective. Nevertheless, it is clear that since the first Inter-American efforts, the relationship between human rights and democracy is present. From the Declaration of Santiago, Chile and the Democratic Charter it is possible to establish that the American States settled as elements of the democracy that they are promoting and protecting: 1) Rule of Law; 2) periodic, free, and fair free elections, requisite that include the necessity of fixed terms of mandates of the presidents establishing periodic elections, based on secret balloting and universal suffrage; 3) respect for human rights such as freedom of information, freedom of expression, freedom of association and social justice based on fundamental rights and it justiciability; 4) a pluralistic system of political parties and organizations, and 5) the separation of powers and independence of the branches of government.

\section{The Elements of RePresentative Democracy}

It is possible to make reference about some necessary elements for representative democracy in the American Continent, from the general overview of the core elements of democracy and the characteristics that the American States gave to the definition of representative democracy. Some of the elements of both views of democracy are repeated, exemplifying that the concept maintains a core and through time additional elements have been added to it.

First, the core of the definition incorporates equality. This could be reflected on the definitions of the Inter-American agreements, within their con-

58 I/A Court H.R., The Word "Laws" in Article 30 of the American Convention on Human Rights, Advisory Opinion OC-6/86 of May 9, 1986, Series A No. 6, para. 34; I/A Court H.R., Case of Castañeda Gutman v. Mexico..., cit., para. 141; I/ A Court H.R., Entitlement of Legal Entities to Hold Rights under the Inter-American Human Rights System (Interpretation and Scope of Article 1(2), in relation to Articles 1(2), 8, 11(2), 13, 16, 21, 24, 25, 29, 30, 44, 46 and 62(3) of the American Convention on Human Rights, as well as of Article 8(1)(A) and (B) of the Protocol of San Salvador), Advisory Opinion OC-22/16 of February 26, 2016, Series A No. 22, para. 31. 
cern to guarantee social justice based on fundamental rights, even through international cooperation.

Second, the core elements include freedom, and the American components include within this concept the freedoms of information and expression of the citizens, for instance.

Third, the requirement of "common will" understood as the interest of the common good is strongly related to rule of law, separation of powers and independence of the branches of the government.

Finally, the element of self-governance can be seen in the element of periodic, free, and fair free elections based on secret balloting and universal suffrage. We would be understanding this component through representation and not necessarily direct participation in the ruling of the society.

The Inter-American States add the requisite of pluralistic system of political parties and organizations.

These elements are going to be analyzed in relation to the Inter-American standards in each topic.

\section{Equality}

Equality must be understood in two different ways, as a descriptive and as a normative concept. Equality in the descriptive sense is "an adjectival relation between entities that are identical in some specific respect". Equality as a normative concept "is the notion that there is some special respect in which all human beings are in fact equal (descriptive) but that this factual equality requires that we treat them in a special way" ${ }^{60}$ For this paper, the main concern will be equality as a normative concept.

The Inter-American Court establishes that the notion of equality

... derives directly from the unity of the nature of the human race and is inseparable from the essential dignity of the person, against which the whole situation which, in relation to a given group, leads to treat it with privilege; or that, conversely, considering it inferior, dealing with hostility or in any way what discriminates the

59 Machan, Tibor R., Liberty and Equality, United States of America, Hoover Institution Press (Stanford University), 2002, p. 1.

60 Idem. 
Esta revista forma parte del acervo de la Biblioteca Jurídica Virtual del Instituto de Investigaciones Jurídicas de la UNAM

relationships of rights that are recognized to those who do not consider themselves involved in such a situation. ${ }^{61}$

In relation to this, the States have the international duty to abstain of any action that can cause de jure or de facto discrimination, ${ }^{62}$ this in accordance with the ius cogens principle of equality.

However, to address equality in a comprehensive way today could be harder than in the Greek times. During the Greek's time, as was explained before, they just didn't consider women and slaves as citizens, but our societies are still working in the inclusion of all the members of the society. The efforts of the States and international organizations to fight inequality is a long fight that has been taking place since years ago. Several groups in position of vulnerability suffered consequences because of unequal practices and realities in different countries. The fight for equality in the enjoyment of rights of women, of indigenous communities, persons in condition of poverty and other vulnerable populations, is something that until now, advocates all around the world are still fighting for.

This topic is particularly concerning given that up to 2017 "Latin America and the Caribbean remain the most unequal regions in the world, with an economic inequality gap that reinforces social and gender inequalities, despite the economic growth over the last decade". ${ }^{63}$ For this reason, concerns about inequality and obligations of the State to fight it are found in almost

61 I/ A Court H.R., Proposed Amendments of the Naturalization Provisions of the Constitution of Costa Rica, Advisory Opinion OC-4/84 of January 19, 1984, Series A No. 4, para. 55; I/A Court H.R., Case of Duque v. Colombia. Interpretation of the Judgment on Preliminary Objections, Merits, Reparations and Costs, Judgment of November 21, 2016, Series C No. 322, para. 109; I/A Court H.R., Gender Identity, and Equality and Non-Discrimination with Regard to Same-Sex Couples. State Obligations in relation to Change of Name, Gender Identity, and Rights Deriving from a Relationship between Same-Sex Couples (Interpretation and Scope of Articles 1(1), 3, 7, 11(2), 13, 17 , 18 and 24, in relation to Article 1, of the American Convention on Human Rights), Advisory Opinion OC-24/17 of November 24, 2017, Series A No. 24, para. 61.

62 I/A Court H.R., Case of Flor Freire v. Ecuador. Preliminary Objection, Merits, Reparations and Costs, Judgment of August 31, 2016, Series C No. 315, para. 110; I/A Court H.R., Gender Identity, and Equality and Non-Discrimination with Regard to Same-Sex Couples..., cit., para. 61.

63 IACHR, Poverty and Human Rights, OEA/Ser.L/V/II.164, Doc. 147, September 7, 2017, para. 105. See also, World Bank, Working to End Poverty in Latin America and the Caribbean. Workers, Jobs, and Wages, June 2015. In this regard, the State of Argentina points out that this report uses the SEDLAC (CEDLAS and the World Bank) database for 2007-2015 (State of Argentina, Input for the IACHR Preliminary Report on "Poverty, Extreme Poverty, and Human Rights in the Americas”, February 6, 2017, p. 4). Thematic Hearing on tax policy and human rights, 156th 
all the aspects of human rights, as economic, social and cultural rights, rights of women, rights of indigenous communities, etc. Nevertheless, given the word limit, for the purposes of the present paper, equality is going to be analyzed only in the sense that it is relevant under the other rights that were recognized by the States as part of representative democracy.

\section{Freedom of Expression and Freedom of Assembly}

This right is protected in several international instruments, ${ }^{64}$ putting in evidence the fundamental importance of this right. The relevance of this right for a democratic society was recognized by principle one of the Declaration of Principles on Freedom of Expression that establishes that freedom of expression "is an indispensable requirement for the very existence of a democratic society". In the same sense, article 4 of the Democratic Charter recognizes the importance of this right for a democratic society. ${ }^{65}$

Freedom of expression is a right contemplated on article 13 of the American Convention on Human Rights (hereinafter also American Convention) also, and this right has had a huge development in the Inter-American System. Article 13 establishes that "everyone has the right to freedom of thought and expression" and that "this right includes freedom to seek, receive, and impart information and ideas of all kinds, regardless of frontiers, either orally, in writing, in print, in the form of art, or through any other medium of one's choice". ${ }^{66}$

period of sessions of the Inter-American Commission on Human Rights (IACHR), Washington, D. C., October 2015.

64 Article 19 of the Universal Declaration on Human Rights, article 19 of the International Covenant on Civil and Political Rights, article 4 of the American Declaration on the Rights and Duties of Man, article 13 of the American Convention on Human Rights, and Article 4 of the Inter-American Democratic Charter.

65 Article 4 of the Inter-American Democratic Charter establish: "Transparency in government activities, probity, responsible public administration on the part of governments, respect for social rights, and freedom of expression and of the press are essential components of the exercise of democracy. The constitutional subordination of all state institutions to the legally constituted civilian authority and respect for the rule of law on the part of all institutions and sectors of society are equally essential to democracy".

66 See also I/ A Court H.R., Compulsory Membership in an Association Prescribed by Law for the Practice of Journalism (Articles 13 and 29 of the American Convention of Human Rights), Advisory Opinion OC-5/85 of November 13, 1985, Series A No. 5, para. 30; I/A Court H.R., Case of Ricardo Canese v. Paraguay. Merits, Reparations and Costs, Judgment of August 31, 2004, Series C 
Esta revista forma parte del acervo de la Biblioteca Jurídica Virtual del Instituto de Investigaciones Jurídicas de la UNAM

This right has three main characteristics. First, as it is established by the mentioned article, it is a right of every person and it can't suffer prior censorship. Article 13 establishes only two exceptions to this rule are accepted and have to be reasons established by law to the extent necessary to ensure: a) respect for the rights or reputations of others; or b) the protection of national security, public order, or public health or morals. In this sense, the Inter-American Court established that this right has to be exercised in a context of respect and safeguard of all other fundamental rights and in this harmonization the State has a main role defining the responsibilities and penalties that may be necessary for this purpose. ${ }^{67}$

Second, this right has both, an individual and a social dimension and both dimensions must be fully guaranteeing simultaneously. ${ }^{68}$ Consequently, freedom of expression requires that no one suffers censorship arbitrarily from expressing his own thoughts and also, that everyone can receive any information and thoughts expressed by others. ${ }^{69}$

Finally, the third element of the right to freedom of expression is that given that this right is essential for a democratic society, the limitations imposed to it must be established by law, ${ }^{70}$ that the right can be limited only through the imposition of sanctions after an abuse but not before the exercise of the right ${ }^{71}$ and limits established must be in accordance to needs compatible with the American Convention itself. ${ }^{72}$ The need implies the existen-

No. 111, para. 77; I/A Court H.R., Case of Kimel v. Argentina. Merits, Reparations and Costs, Judgment of May 2, 2008, Series C No. 177, para. 53.

67 I/A Court H.R., Case of Kimel v. Argentina..., cit., para. 53; I/A Court H.R., Case of Tristán Donoso v. Panama. Preliminary Objection, Merits, Reparations and Costs, Judgment of January 27, 2009, Series C No. 193, para. 112.

68 I/A Court H.R., Compulsory Membership in an Association Prescribed by Law for the Practice..., cit., paras. 31 and 32; I/A Court H.R., Case of Granier et al. (Radio Caracas Televisión) v. Venezuela. Preliminary Objections, Merits, Reparations and Costs, Judgment of June 22, 2015, Series C No. 293, para. 135; I/A Court H.R., Case of "The Last Temptation of Christ"(Olmedo Bustos et al.) v. Chile. Merits, Reparations and Costs, Judgment of February 5, 2001, Series C No. 73, para. 67.

69 I/A Court H.R., Compulsory Membership in an Association Prescribed by Law for the Practice..., cit., para. 30; I/A Court H.R., Case of Granier et al. (Radio Caracas Televisión) v. Venezuela..., cit., para. 136.

70 I/A Court H.R., Compulsory Membership in an Association Prescribed by Law for the Practice..., cit., para. 40 .

71 Ibidem, para. 39.

72 I/ A Court H.R., Case of Kimel v. Argentina..., cit., para. 56; I/ A Court H.R., Case of Fontevecchia and D'Amico v. Argentina. Merits, Reparations and Costs, Judgment of November 29, 2011, Series C No. 238, para. 50. 
ce of an "imperious social need", particularly in matters of public interest, because it "is a cornerstone of the very existence of a democratic society". ${ }^{73}$

The Special Rapporteur on Freedom of Expression of the Inter-American Commission on Human Rights (hereinafter also IACHR) stated that "in a democratic society, given the importance of monitoring the conduct of public affairs through opinion, there is a narrower margin for any restriction of political debate or discourse on matters of public interest" ${ }^{74}$ In this sense, the IACoHR establishes that "without an effective guarantee of freedom of expression the democratic systems is weakened and there is a breakdown of pluralism and tolerance; the mechanisms of control and complaint that citizens have may become inoperable and, indeed, a fertile ground is created for authoritarian systems to take root" ${ }^{75}$

It is important to mention the relevant relationship between freedom of expression and freedom of assembly. The IACoHR recognized the right to defend democracy as a "specific manifestation of the right to take part in public affairs and... the exercise of other rights such as freedom of expression and the right of assembly". ${ }^{76}$

Article 15 of the American Convention recognizes "the right of peaceful assembly, without arms". In relation to this right, the IACoHR establishes that the "ability to protest publicly and peacefully is one of the most accessible ways to exercise the right to freedom of expression, and can contribute to the protection of other rights". ${ }^{77}$ For this reason, the right of assembly is a

73 I/ A Court H.R., Compulsory Membership in an Association Prescribed by Law for the Practice..., cit., para. 70; I/A Court H.R., Case of Granier et al. (Radio Caracas Televisión) v.Venezuela..., cit., para. 140; I/ A Court H.R., Case of Carvajal Carvajal et al. v. Colombia. Interpretation of the Judgment on Merits, Reparations and Costs, Judgment of November 21, 2018, Series C No. 365, para. 174.

74 IACHR, Inter-American Legal Framework Regarding the Right to Freedom of Expression, Office of the Special Rapporteur for Freedom of Expression, OEA/Ser.L/V/II/CIDH/RELE/ INF.2/09, December 30, 2009, para. 36; IACHR, Annual Report 2018, Office of the Special Rapporteur for Freedom of Expression, OEA/Ser.L/V/II.Doc. 30, March 17, 2019, para. 13.

75 I/A Court H.R., Case of Herrera Ulloa v. Costa Rica. Preliminary Objections, Merits, Reparations and Costs, Judgment of July 2, 2004, Series C No. 107, para. 116; I/A Court H.R., Case of Granier et al. (Radio Caracas Televisión) v.Venezuela..., cit., para. 140.

76 I/ A Court H.R., Case of López Lone et al. v. Honduras. Preliminary Objection, Merits, Reparations and Costs, Judgment of October 5, 2015, Series C No. 302, para. 164.

77 Ibidem, para. 167. See also, United Nations, Resolution of the Human Rights Council on the promotion and protection of human rights in the context of peaceful protests, A/HRC/ RES/19/35, March 23, 2012; Resolution of the Human Rights Council on the promotion and protection of human rights in the context of peaceful protests, A/HRC/RES/22/10, March 
Esta revista forma parte del acervo de la Biblioteca Jurídica Virtual del Instituto de Investigaciones Jurídicas de la UNAM

basic right in a democratic society and hence has to be protected. Similar to the right of freedom of expression, any restriction to the right to assembly must be established by law, "pursue a legitimate purpose, and comply with the requirements of suitability, necessity and proportionality". ${ }^{78}$

In conclusion, freedom of expression and freedom of assembly has a strong interdependence with democracy as it is understood by the American States. The population of a State has the right to defend democracy through these two rights. Consequently, any democratic State can't systematically violate this right and continue being a democracy.

\section{Political Rights}

\section{Freedom of Association and Political Parties}

The right of association is recognized in the American Convention in its article 16 establishing that "everyone has the right to associate freely for ideological, religious, political, economic, labor, social, cultural, sports, or other purposes". The free exercise of this right can only be restricted by law for reasons of "national security, public safety or public order, or to protect public health or morals or the rights and freedoms of others". That is stressed in the American Convention as a necessary element of a democratic society, as it has also been stated by the IACHR. ${ }^{79}$

The IACoHR recognized this right in order to achieve a legitimate common objective, "without pressure or interference that could alter or dena-

21, 2013, and Resolution of the Human Rights Council on the promotion and protection of human rights in the context of peaceful protests, A/HRC/25/L.20, March 24, 2014.

78 I/ A Court H.R., Case of López Lone et al. v. Honduras..., cit., para. 168; I/ A Court H.R., The Word "Laws" in Article 30..., cit., paras. 35 and 37; I/A Court H.R., Case of Artavia Murillo et al. (In Vitro Fertilization) v. Costa Rica. Preliminary Objections, Merits, Reparations and Costs, Judgment of November 28, 2012, Series C No. 257, para. 273. See also, on the right to freedom of expression: I/ A Court H.R., Case of Herrera Ulloa v. Costa Rica..., cit., para. 120; I/ A Court H.R., Case of Fontevecchia and D'Amico v. Argentina..., cit., para. 43; I/A Court H.R., Case of Mémoli v. Argentina. Preliminary Objections, Merits, Reparations and Costs, Judgment of August 22, 2013, Series C No. 265, para. 127.

79 IACHR, Report on Terrorism and Human Rights, OEA/Ser.L/V/ll.116, Doc. 5 rev. 1 corr., Washington, October 22, 2002, para. 359, available at: http://www.cidh.org/terrorism/eng/ toc.htm. 
ture this objective". ${ }^{80}$ However, this right also has positive obligations for the State, because the Inter-American Court has established the obligation of the State "to prevent any attacks on it, to protect those who exercise it, and to investigate any violations thereof". ${ }^{81}$

In this sense, the ILO Committee on Freedom of Association established that an environment of violence constituted an important obstacle for the exercise of freedom of association. ${ }^{82}$ For this reason the Inter-American Court settled that only when human rights are fully respected and guaranteed, in particular the right to life and safety, the right to freedom of association can be exercised. ${ }^{83}$

Usually, this right is analyzed in relation to political parties. The IACoHR settled the "importance of political parties as essential forms of association for the development and strengthening of democracy are not discounted". ${ }^{84}$ This is particularly important because as has been established "the responsibility for filtering out authoritarians lies in political parties and party leaders" as democracy's gatekeepers. ${ }^{85}$ Levitsky and Ziblatt explain that five reasons make political parties democracy's gatekeepers. First, because they can keep "would-be authoritarians off party ballots at election time", by not

80 I/A Court H.R., Case of Baena Ricardo et al. v. Panama. Merits, Reparations and Costs, Judgment of February 2, 2001, Series C No. 72, para. 156; I/A Court H.R., Case of García and Family Members v. Guatemala. Merits, Reparations and Costs, Judgment of November 29, 2012, Series C No. 258, para. 116; I/ A Court H.R., Case of Lagos del Campo v. Peru. Interpretation of the Judgment on Preliminary Objections, Merits, Reparations and Costs, Judgment of November 21, 2018 , Series C No. 366, para. 155.

81 I/A Court H.R., Case of Huilca Tecse v. Peru. Merits, Reparations and Costs, Judgment of March 3, 2005, Series C No. 121, para. 76; I/ A Court H.R., Case of Lagos del Campo v. Peru..., cit., para. 155 .

82 Report of the Committee on Freedom of Association of the International Labour Organization, No. 278 with regard to Peru (vol. LXXIV, 1991, Series B, No. 2), para. 237, available at: http: / / www.oit.org.pe/sindi/casos/per/per22.html.

83 I/A Court H.R., Case of Huilca Tecse v. Peru..., cit., para. 75.

84 I/A Court H.R., Case of Yatama v. Nicaragua. Preliminary Objections, Merits, Reparations and Costs, Judgment of June 23, 2005, Series C No. 127, para. 215. See also: ECHR, Refah Partisi (the Welfare Party) and Others v. Turkey [GC], nos. 41340/98, 41342/98, 41343/98 and 41344/98, $\S 87$, ECHR 2003-II; ECHR, Case of Yazar and Others v. Turkey, nos. 22723/93, 22724/93 and 22725/93, § 32, ECHR 2002-II; ECHR, Case of Socialist Party and Others v. Turkey, Judgment of 25 May 1998, Reports of Judgments and Decisions 1998-III, para. 29.

85 Levitsky, Steven and Ziblatt, Daniel, How Democracies Die, United States of America, Crown, 2018, p. 24. 
nominating them. ${ }^{86}$ Second, because parties "can root out extremists in the grass roots of their own ranks". ${ }^{87}$ Third, "prodemocratic parties can avoid all alliances with antidemocratic parties and candidates" ${ }^{88}$ Four, because democratic parties can isolate extremist instead of legitimize them. ${ }^{89}$ Finally, because "whenever extremist emerge as serious electoral contenders, mainstream parties must forge united front to defeat them". ${ }^{90}$

Given this importance, political parties must have aims that are compatible with the rights and freedoms established in the American Convention. ${ }^{91}$ Otherwise, the right could be limited by "national security, public safety or public order, or to protect public health or morals or the rights and freedoms of others" as is established in the American Convention.

In conclusion, the right to freedom of association and its protection is essential for the maintenance of a democratic society and hence it has to be protected by democratic States. However, this also means that political parties as an expression of the right to assembly, have to be in accordance with the other rights and purposes of the American Convention.

\section{Right to Participate in a Government}

Article 23 of the American Convention recognizes political rights. The mentioned article is composed by different expressions of the broad right that is political rights. For this reason, it is better to analyze each part of the article independently.

i. The Right to Political Participation

(Political Rights Latu Sensu)

Article 23.1.a) establishes that every citizen should be able "to take part in the conduct of public affairs, directly or through freely chosen representatives". This is probably the element of the "new" definition of democracy

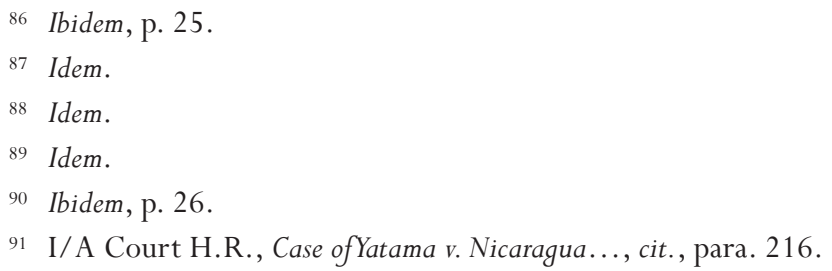


that is more loyal to the original meaning created by the Greeks. Similar to the Greeks in their moment, the IACoHR has pointed that States have an obligation to guarantee the enjoyment and application of this right according to the principles of equality and non-discrimination, and "shall adopt the necessary measures to guarantee its full exercise... considering the situation of weakness and destitution of the members of certain sectors or social groups". ${ }^{92}$ Therefore, the American States have to create optimum conditions and mechanisms to guarantee the effective exercise of political rights. ${ }^{93}$

In relation to equality in the right to political participation, the IACoHR made a very important approach in the case of Chitay Nech et al. v. Guatemala in which it understood that political representation is a prerequisite for the realization of self-determination, the development and the inclusion of groups in conditions of inequality within a plural and democratic State. ${ }^{94}$ In this statement, it is possible to identify two elements of the core of democracy, first equality and the effort to pursue it, and two, the application of the Aristotle concept of polity, excluding the problem of democracy seen just as the will of the majority.

Furthermore, it has been recognized that "the effective exercise of political rights constitutes a goal in itself, and at the same time, a fundamental means that democratic societies have to guarantee the other human rights established in the Convention". ${ }^{95}$ From this affirmation, it is possible to conclude then that democracy guarantees human rights, and political rights are just one of the means to do so.

92 Ibidem, para. 201; I/A Court H.R., Juridical Condition and Rights of Migrants, Advisory Opinion OC-18/03 of September 17, 2003, Series A No. 18, para. 89; I/A Court H.R., Juridical Condition and Human Rights of the Child, Advisory Opinion OC-17/02 of August 28, 2002, para. 46; I/ A Court H.R., Case of Manuel Cepeda Vargas v. Colombia. Preliminary Objections, Merits, Reparations and Costs, Judgment of May 26, 2010, Series C No. 213, para. 173; I/A Court H.R., Case of Chitay Nech et al. v. Guatemala. Preliminary Objections, Merits, Reparations and Costs, Judgment of May 25, 2010, Series C No. 212, para. 106. See also, Human Rights Commission, General Observation No. 25: Participation in Public Matters, the Right to Vote, HRI/GEN/1/Rev.7 at 194 (1996).

93 I/ A Court H.R., Case of Yatama v. Nicaragua..., cit., para. 143.

94 I/A Court H.R., Case of Chitay Nech et al.v. Guatemala..., cit., para. 113.

95 Ibidem, para. 107; UN, Human Rights Council, "Background Document by the Independent Expert on Minority Issues, Gay McDougall, on Minorities and Effective Political Participation”, Forum on Minority Issues, Geneva, 12 and 13 November 2009, para. 1. 


\section{ii. The Right to Vote and Right to Political-Electoral Participation in Conditions of Equality and Non- Discrimination (Political Rights Strictu Sensu)}

Article 23.1.b) establishes that every citizen shall enjoy the same rights and opportunities "to vote and to be elected in genuine periodic elections, which shall be by universal and equal suffrage and by secret ballot that guarantees the free expression of the will of the voters". States may establish minimum standards to regulate political participation. This regulation has to be reasonable and compatible with the principles of representative democracy. ${ }^{96}$ Also bearing in mind that Article 6 of the Inter-American Democratic Charter, determines that "[p]romoting and fostering diverse forms of participation strengthens democracy" and for this reason, it is important that States consider all the sectors of the society in the creation of the regulation.

In reference to the restrictions of this right, the States have to respect the principles of legality, necessity and proportionality in a democratic society. ${ }^{97}$ Meaning that the restrictions have to be defined precisely by law. "[T]he requirements for voters to be able to take part in the elections, and to stipulate clearly the electoral procedures prior to the elections", ${ }^{98}$

...non-discriminatory, based on reasonable criteria, respond to a useful and opportune purpose that makes it necessary to satisfy an urgent public interest, and be proportionate to this purpose. When there are several options to achieve this end, the one that is less restrictive of the protected right and more proportionate to the purpose sought should be chosen. ${ }^{99}$

96 I/A Court H.R., Case of Yatama v. Nicaragua..., cit., para. 207.

97 Ibidem, para. 206.

98 Idem.

99 I/ A Court H.R., Case of Ricardo Canese v. Paraguay..., cit., paras. 96 and 133; I/ A Court H.R., Case of Herrera Ulloa v. Costa Rica..., cit., paras. 121 and 123; I/ A Court H.R., Compulsory Membership in an Association Prescribed by Law for the Practice..., cit., para. 46. Also see, ECHR, Case of Barthold v. Germany, Judgment of March 25, 1985, Series A No. 90, para. 58; ECHR, Case of Sunday Times v. United Kingdom, Judgment of April 26, 1979, Series A No. 30, para. 59; UN, Human Rights Committee, General Comment No. 27: Freedom of Movement (Art. 12), November 2, 1999, paras. 14 and 15; UN, Human Rights Committee, General Comment No. 25: Right to Participate in Public Affairs, Voting Rights and the Right of Equal Access to Public Service (Art. 25), July 12, 1996, paras. 11, 14, 15 and 16. 


\section{iii. Access and Permanence on Equal Terms to Political Positions}

Article 23.1.b) establishes that every citizen shall enjoy the same rights and opportunities "to have access, under general conditions of equality, to the public service of his country". In the case of Apitz Barbera et al. ("First Court of Administrative Disputes") v. Venezuela, it was stated that this article does not establish the guarantee to access a public position, but to do so in "general conditions of equality". ${ }^{100}$ This means that the respect and guarantee of this right are fulfilled when "the criteria and procedures for the appointment, promotion, suspension and dismissal [are] reasonable and objective" and when "the people are not object of discrimination" in the exercise of this right. ${ }^{101}$

However, the Human Rights Committee has interpreted that the guarantee of protection includes both, the access and the continuance in equal conditions and non-discrimination. ${ }^{102}$ In this perspective, the IACoHR established that the access in equal conditions also has to be effective. ${ }^{103}$

In conclusion, the American States have obligations in order to guarantee political rights to its citizens. Particularly, States have to take measures to make these rights effective and in accordance with the principles of equality and non-discrimination.

\section{Judicial Independence}

Even though from the review made, the core element that appears is the separation of powers and the independence of the branches of the State,

100 I/A Court H.R., Case of Apitz Barbera et al. ("First Court of Administrative Disputes") v.Venezuela. Preliminary Objection, Merits, Reparations and Costs, Judgment of August 5, 2008, Series C No. 182, para. 206.

101 Idem; I/A Court H.R., Case of Reverón Trujillo v. Venezuela. Preliminary Objection, Merits, Reparations and Costs, Judgment of June 30, 2009, Series C No. 197, para. 138. See also, UN, Human Rights Committee, General Comment No. 25: The Participation in Public Matters and the Right to Vote, CCPR/C/21/Rev.1/Add.7, July 12, 1996, para. 23.

102 Human Rights Committee, Pastukhov v. Belarus (814/1998), ICCPR, A/58/40 vol. II (5 August 2003) 69 (CCPR/C/78/D/814/1998) at paras. 7(3) and 9; Human Rights Committee, Adrien Mundyo Buyso, Thomas OsthudiWongodi, René Sibu Matubuka et al. v. Democratic Republic of the Congo (933/2000), ICCPR, A/58/40 vol. II (31 July 2003) 224 (CCPR/C/78/D/933/2000) at para. 5(2).

103 I/A Court H.R., Case of Yatama v. Nicaragua..., cit., para. 195. 
Esta revista forma parte del acervo de la Biblioteca Jurídica Virtual del Instituto de Investigaciones Jurídicas de la UNAM

in the Inter-American System this topic is not clearly defined on a binding international instrument. Under article 8.1 of the American Convention, "every person has the right to a hearing... by a competent, independent and impartial tribunal", and this is the only power of the State that has its independence guaranteed by the Convention. Not even the Democratic Charter mentions something about this subject, apart from article 3 that included the separation of powers of the State as an element of representative democracy.

However, the IACoHR does recognize that this protection of judicial independence is related with the principle of the separation of powers which is an essential aspect of the rule of law, and that the judicial function plays an important role in a democracy. ${ }^{104}$ Even though the Court didn't define the principle of separation of powers, it is understood as the requirement to divide the three branches of power of a States (executive, legislative and judicial power) in person and function, and they must act independently one from the other, limiting the possibility that one branch exercise the core functions of other branch. As was established by Montesquieu, this is a way to safeguard liberties and guard them against tyranny. ${ }^{105}$

Some principles used by the Inter-American Court ${ }^{106}$ to analyze judicial independence expressly recognize the importance of protecting this independence. The United Nations Basic Principles on the Independence of the Judiciary (hereinafter also the United Nations Basic Principles) recognize that "the independence of the judiciary shall be guaranteed by the State and enshrined in the Constitution or the law of the country. It is the duty of all governmental and other institutions to respect and observe the independence of the judiciary". ${ }^{107}$ In addition, the Bangalore Principles of Judicial

104 I/A Court H.R., Case of the Constitutional Tribunal (Camba Campos et al.) v. Ecuador. Preliminary Objections, Merits, Reparations and Costs, Judgment of August 28, 2013, Series C No. 268, para. 198.

105 Evans, T. and Davies, W., The CompleteWork of M. de Montesquieu. Translated from the French in FourVolumes, vol. I: The Spirit of Laws, 1777, pp. 198 and 199, available at: http: / /lf-oll.s3.ama zonaws.com/titles/837/0171-01_Bk_Sm.pdf.

106 I/A Court H.R., Case of the Constitutional Tribunal (Camba Campos et al.) v. Ecuador..., cit.; I/ A Court H.R., Case of López Lone et al. v. Honduras. Preliminary Objection, Merits, Reparations and Costs, Judgment of October 5, 2015, Series C No. 302.

107 United Nations Basic Principles on the Independence of the Judiciary adopted by the Seventh United Nations Congress on the Prevention of Crime and the Treatment of Offenders held in Milan from 26 August to 6 September 1985 and endorsed by General Assembly resolutions 40/32 of 29 November 1985 and 40/146 of 13 December 1985, principle 1. 
Conduct establish that "judicial independence is a pre-requisite to the rule of law and a fundamental guarantee of a fair trial. A judge shall therefore uphold and exemplify judicial independence in both its individual and institutional aspects". ${ }^{108}$ The IACoHR had reinforced this last obligation of the State to "guarantee the autonomous exercise of the judicial function in both its institutional aspect, that is in relation to the Judiciary as a system, and also in relation to its individual aspect, that is, as regards the person of the specific judge". ${ }^{109}$

Bearing in mind the mentioned above, the Inter-American Court establishes that:

...(i) respect for judicial guarantees entails respect for judicial independence; (ii) the dimensions of judicial independence result in the subjective right of the judge that his removal from office is exclusively for the causes permitted, either by means of a procedure that complies with judicial guarantees or because the term or period of his mandate has ended, and (iii) when the permanence of judges in office is arbitrarily affected, the right to judicial independence established in Article 8(1) of the American Convention is violated, in conjunction with the right of access to and permanence in public service, under general conditions of equality, established in Article 23(1)(c) of the American Convention. ${ }^{110}$

In conclusion, the judicial independence is an essential element of a representative democracy and the IACoHR already recognize the relevance of this right, its relationship with the principle of separation of powers and with democracy. Also, it is possible to understand why the states only included the protection to the judicial independence in the American Declaration. In this context, this is the branch of the State in charge of investigating, prosecuting and sanctioning if other members of the other powers threat the democracy of the State.

108 Bangalore Principles of Judicial Conduct adopted by the Judicial Group on Strengthening Judicial Integrity, as revised at the Round Table Meeting of Chief Justices held at the Peace Palace, The Hague, November 25 and 26, 2002, principle 1.

109 I/A Court H.R., Case of Apitz Barbera et al. ("First Court of Administrative Disputes") v. Venezuela..., cit., para. 55; I/A Court H.R., Case of the Constitutional Tribunal (Camba Campos et al.) v. Ecuador..., cit., para. 198.

110 I/A Court H.R., Case of the Constitutional Tribunal (Camba Campos et al.) v. Ecuador..., cit., para. 199. 


\section{CONCLUSION}

Representative democracy is a fundamental concern of the States of the Americas. The core of the concept of representative democracy in the Americas is composed by several human rights established by the own States and that are compatible with the main characteristics of a democracy since the Greeks and its evolution over time. Five elements can be identified in the jurisprudence of the Inter-American System that are consistent with the elements found in the history and development of the concept in the continent. These five human rights are: 1) equality; 2) freedom of assembly; 3) freedom of expression; 4) political rights, and 5) judicial independence.

So, even when additional elements and rights can be added to the definition of representative democracy, anyone in the continent should be able to talk about democracy if is incurring in a systematic or in recurrent violations of one of the five rights mentioned before. This must not be understood as a limitation of the rights that constitute a democracy or that this frame of rights are the only ones that can't be violated to be in a democracy. These five rights are the basis since early times, the minimum core of democracy. Other rights are also necessary for a free and pluralistic society capable of maintain a healthy democracy.

It is not totally clear if democracy is a right, even with the article of the Democratic Charter, because in some articles of international instruments it seems that democracy is just the means to comply with human rights, and in others a right in itself. This will be an interesting question for further research. However, from the entire analysis made before, it is possible to conclude that representative democracy requires American States to guarantee some minimum standards to protect and guarantee: 1) equality; 2) freedom of assembly; 3) freedom of expression; 4) political rights, and 5) judicial independence.

\section{ACKNOWLEDGEMENTS}

This paper was written as part of a directed reading with the Professor Paolo Carozza in the LL.M. in International Human Rights Law, University of Notre Dame. 


\section{BIBLIOGRAPHY}

ARRIGHI, Jean Michel, "El sistema interamericano y la defensa de la democracia”, Agenda Internacional, vol. 16, no. 27, 2009.

Coppedge, Michael, Democratization and Research Methods, New York, Cambridge University Press, 2013.

DAHL, Robert, Democracy and its Critics, Yale University, 1989.

Evans, T. and DAVIES, W., The Complete Work of M. de Montesquieu. Translated from the French in Four Volumes, vol. I: The Spirit of Laws, 1777, available at: http: / /1f-oll.s3.amazonaws.com/titles/837/0171-01_Bk_Sm.pdf.

Harrison, Ross, Democracy, London-New York, Routledge, 1993.

HELD, David, Models of Democracy, 3rd. ed., Great Britain, Stanford University Press, 2006.

Human Rights CounciL, "Background Document by the Independent Expert on Minority Issues, Gay McDougall, on Minorities and Effective Political Participation”, Forum on Minority Issues, Geneva, 12 and 13 November 2009.

IACHR, Annual Report 2018, Office of the Special Rapporteur for Freedom of Expression, OEA/Ser.L/V /II.Doc. 30, March 17, 2019.

IACHR, Inter-American Legal Framework Regarding the Right to Freedom of Expression, Office of the Special Rapporteur for Freedom of Expression, OEA/ Ser.L/V / II / CIDH/RELE/INF.2 / 09, December 30, 2009.

IACHR, Poverty and Human Rights, OEA/Ser.L/V/II.164, Doc. 147, September 7, 2017.

IACHR, Report on Terrorism and Human Rights, OEA/Ser.L/V/ll.116, Doc. 5 rev. 1 corr., Washington, October 22, 2002, available at: http: / / www. cidh.org/terrorism/eng/toc.htm.

INTER-AMERICAN JURIDICAL COMMITTEE, "Elementos esenciales y fundamentales de la democracia representativa y su vinculación con la acción colectiva en el marco de la Carta Democrática Interamericana”, Resolution CJI/RES (LXXXV-O/09), August 12, 2009, available at: https: / / archivos.juridicas.unam. $\mathrm{mx}_{\mathrm{w}} / \mathrm{ww}_{\mathrm{w}} /$ bjv/libros $/ 11 / 5130 / 30$.pdf.

LakofF, Sanford, Democracy: History, Theory, Practice, New York, Westview Press, 1996. 
LEVITSKY, Steven and ZiblatT, Daniel, How Democracies Die, United States of America, Crown, 2018.

MaCHAN, Tibor R., Liberty and Equality, United States of America, Hoover Institution Press (Stanford University), 2002.

OAS, "Tenth Anniversary of the Inter-American Democratic Charter was Commemorated in Chile with a Renewed Commitment of the Americas with Democracy", 2011, available at: https://www.oas.org/En/media_cen ter/press_release.asp?sCodigo $=E-816 / 11$.

ORWELL, George, "Politics and the English Language", A Collection of Essays, United States of America, Harcourt Brace Jovanovich, 1946.

Pateman, Carole, Participation and Democratic Theory, Australia, Cambridge University Press, 1970.

SPRINGbORG, Patricia, "Karl Marx on Democracy, Participation, Voting, and Equality”, Political Theory, vol. 12, no. 4, 1984. 